\section{Characterization and Properties of a New Placental Protein}

PIACENTA is the source of several protein hormones described recently ${ }^{1-4}$. While working on a new method for making one of them, human placental lactogen, we found a new protein with hormonal properties, and we describe here its preparation and characterization.

A recently eliminated, membrane-free human placenta was homogenized in a Waring blender, freeze-dried, ground and extracted overnight with $450 \mathrm{ml}$. of $0.1 \mathrm{~N}$ acetic acid at $4^{\circ} \mathrm{C}$. The supernatant was collected by centrifugation at 1,500 r.p.m. for $15 \mathrm{~min}$ and then freeze. dried. One hundred $\mathrm{mg}$ of it was then dissolved in $4 \mathrm{ml}$. of $0 \cdot 1 \mathrm{~N}$ acetic acid and then chromatographed in a 'Sephadex G-75' column of $100 \times 1 \mathrm{~cm} ; 0.1 \mathrm{~N}$ acetic acid was used as eluent and $3 \mathrm{ml}$. fractions were collected in an automatic fraction collector.

Protein was assayed in each fraction by the method of Lowrys. Two principal peaks of protein were obtained, $A$ and $B$, as shown in Fig. 1; the protein fractions thus obtained were tested against antiserum anti-HGH according to the immunodiffusion technique of Ouchterlony ${ }^{6}$; only the second peak showed a positive reaction of partial identity with the $\mathrm{HGH}$ prepared by the method of Raben?. This second peak could possibly correspond to the human placental lactogen described by Josimovich and MacLaren ${ }^{3}$ and Kaplan and Grumbeck ${ }^{4}$.

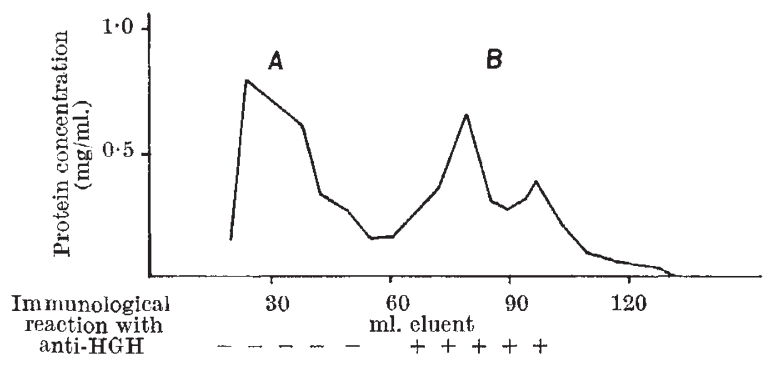

Fig. 1. Gel filtration on 'Sephadex $G-75$ ' of a placental protein extract.

The protein fraction contained in pcak $A$ (Fig. 1) was concentrated by freezc-drying and redissolved in the appropriate solvent for each of the following exporiments.

The purity of this protein fraction was cstablished by electrophoresis on collulose acetate strips. The lyophilized protein was dissolved in $0.33 \mathrm{M}$ boric acid- $0 \cdot 1 \mathrm{M} \mathrm{LiOH}$ buffer $p \mathrm{H} 8$ and submitted to electrophoresis in the same buffer for $90 \mathrm{~min}$ at $25 \mathrm{~V} / \mathrm{cm}$; protein was then stained on a 0.5 per cent solution of water-soluble nygrosin in methanol-acetic acid-water $50: 10: 40$ (ref. 8). Only one band of protcin was obtained with a mobility of $+3 \mathrm{~cm}$. Analytical chromatography in 'Sephadex G-100' using $0.05 \mathrm{M}$ tris buffer $p \mathrm{H} 8$ as solvent and cluent also revealed only one symmetrical peak of protein with a molecular weight of approximately 70,000 according to the method of Andrews".

Comparative studies with $\mathrm{HGH}, \mathrm{ACTH}, \mathrm{HPL}, \mathrm{CGT}$ and TSH and albumin were made in order to establish the distinct identity of peak $A$. Zone electrophoresis, immunodiffusion, immunoelectrophoresis as well as haemagglutination showed non-identity with all these protein hormones; we were able to show that cross-contamination was less than 1 per cent.

The injection of peak $A$ dissolved in saline, in doses of $30 \mu \mathrm{g} /$ day to young female rats, produced a significant increase in uterus weight $(P=0.00 \mathrm{I})$. This effect was completely inhibited by the simultaneous injection of antiserum anti-peak $A$ prepared in rabbits, as shown in Fig. 2.

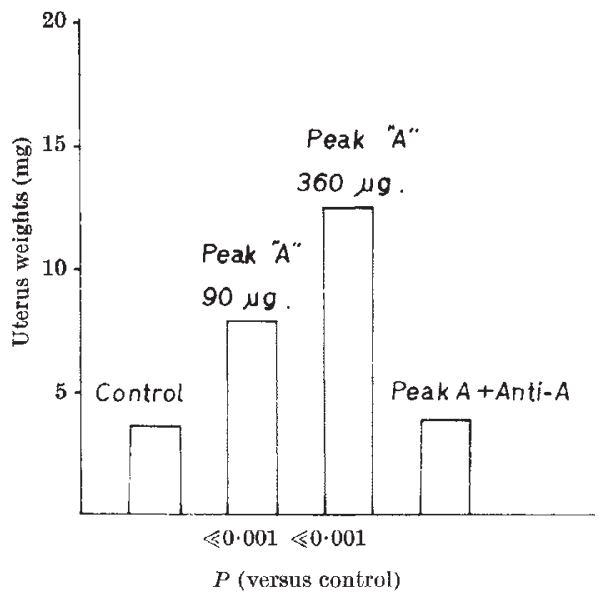

Fig. 2. Action of the placental protein and its antiserum on the weights of the uterus of rats.

The results of these preliminary experiments towards the hormonal activity of our protein fraction lead us to suggest the provisional name of "placental uterotrophic hormone" for this new placental protein. The physiological role of the protein is being investigated in our laboratory.

\section{Franctsco Beas}

Hernando Flores

Laboratorio de Investigaciones Pediátricas,

Universidad de Chile, Casilla 5370,

Santiago, Chile.

Received November 18, 1968.

${ }^{1}$ Bcas, F., and Flores, H., Third Intern. Cong. Endocrinol., Mexico, No. 157, 200 (1968).

${ }^{2}$ Beas, F., Salinas, A., and Pak, N. (in the press).

${ }^{3}$ Josimovich, I. B., and MacLaren, J. A., Endocrinology, 11, 209 (1962).

${ }^{4}$ Kaplan, S. L., and Grumbeck, M. M., J. Clin. Endocrinol. Metab., 24, 80 (1964).

${ }^{5}$ Lowry, O. H., Rosebrough, N. I., Farr, A. C., and Randall, R. I., .T. Biol. Chem, 198, $265(1951)$

${ }^{8}$ Ouchterlony, O., Acta Path. Microbiol. Scand., 32, 231 (1053).

7 Raben, M. S., Science, 125, 883 (1957).

Barrett, R. I., Friesen, H., and Astwood, E. B., J. Biol, Chem., 23\%, 432 (1962).

'Andrews, P., Biochem. .J., 91 (2), 222 (1964).

\section{Control of Cholesterol Biosynthesis by a Plasma Apo-lipoprotein}

Mevalonio acid (MVA) is well known as a precursor of cholesterol ${ }^{1}$, and it is also established that squalene is an intermediate in the biosynthesis of cholesterol ${ }^{2,3}$. When liver microsomes plus the coll sap are incubated with $2-{ }^{14} \mathrm{C}$ mevalonic acid in air, most of the radioactivity is incorporated into cholesterol and very little radioactivity is associated with squalene. Conversely, in anaerobic conditions squalene accumulates ${ }^{4,5}$. We have oncountered an interesting situation in which squalene accumulates during cholesterologenesis in aerobic conditions.

A rat liver homogenate was prepared in Bucher's medium ${ }^{6}$, and centrifuged at $18,000 \mathrm{~g}$ for $20 \mathrm{~min}$. The $18,000 \mathrm{~g}$ supernatant containing microsomes plus the cell sap was incubated with $2 .{ }^{14} \mathrm{C}$ DL-MVA (Radiochemical Centre, Amersham), NADPH generating system, NADH, ATP generating system and reduced glutathione at $37^{\circ} \mathrm{C}$ in air for $1-1.5 \mathrm{~h}$. In these incubations about $30-40$ per cent of the ${ }^{2-14} \mathrm{C}$ DL-MVA was converted to sterols-the L-isomer of mevalonic acid is not incor- 